\title{
ПСИХОТЕРАПЕВТИЧНА ТЕХНІКА «СІМЕЙНА СКРИНЯ» В ПСИХОЛОГІЧНОМУ СУПРОВОДІ СІМЕЙ, ЩО МАЮТЬ ПРОБЛЕМНИХ ДІТЕЙ
}

\author{
Мушкевич Мирослава \\ Східноєвропейський національний університет імені Лесі Українки \\ Луцьк, Україна \\ mira_mush@yahoo.com \\ https://orcid.org/0000-0002-3268-5767
}

\begin{abstract}
Mema. У статті презентовано результати використання в процесі психологічного супроводу психотерапевтичної техніки «Сімейна скриня». Методи. Описано основні підходи до застосування психотехніки, під час реалізації якої клієнтові пропонують уявити образ сімейної скрині, передбачаючи, що в описі будуть представлені незадоволені сімейні та особистісні потреби, конфлікти або афекти, що утворюють зміст несвідомого. Указано, що образи, пов'язані 3 несвідомим, досить універсальні й мають статус архетипових образів, що співвідносяться з екзистенційними життєвими ситуаціями. Результати. Констатовано, що в експериментальній групі внаслідок упровадження техніки на етапі контрольного діагностичного зрізу частота вираження позитивної модальності всіх визначених емпіричних показників достовірно вища за частоту вираження такої в контрольній групі. Засвідчено, що серед представників експериментальної вибірки кількість членів сімей проблемних дітей зі сформованою настановою на позитивне сприйняття й прийняття партнера або інших членів ядерної сім’і, із відрефлексованою позицією та готовністю до генерування конструктивного простору подружніх і сімейних взаємин, культивування «здорових» сімейних цінностей та настанов, реалізації конструктивних рольових патернів сімейного функціонування виявилася більшою, ніж серед представників контрольної вибірки. Відзначено, що рівень формування особистісної настанови на позитивне сприйняття й прийняття партнера або інших членів ядерної сім'ї в членів сімей проблемних дітей у межах упровадження психотерапевтичної техніки в 4,5 раза вищий. Висновки. Доведено, що важливим компонентом психологічного супроводу сімей, що мають проблемних дітей, є психотерапевтичний етап із використанням психотехніки «Сімейна скриня», спрямованої на розвиток позитивних змін щодо сімейних цінностей, сімейних ролей, сімейних установок, особливостей подружніх i сімейних взаємин та ставлення, прийняття партнера чи інших членів ядерної сім’і, що стали мішенями психологічного супроводу. Зазначено, що перспективними напрямами подальших досліджень є вдосконалення програми психологічного супроводу сімей, що мають проблемних дітей, складання емпірико-
\end{abstract}

ISSN 2308-3743 (Online), ISSN 2227-1376 (Print)

(C) Мушкевич М., 2020. Ця стаття відкритого доступу на умовах CC BY-NC 4.0 
діагностичних програм формування змісту психологічного супроводу сімей із використанням ефективних психотерапевтичних технік.

Ключові слова: сім'я, ядерна сім'я, проблемна дитина, психотерапія, психотехніка, сімейні установки, сімейні ролі, психологічний супровід.

Mushkevych Myroslava. The Psychotherapeutic Technique «Family Chest» with the Psychological Support of Families that Have Problem Children. Purpose. The article presents the results of using the Family Chest technique in the process of psychological support of the psychotherapeutic technique. Methods. The main approaches to the use of psychotechnique are described, in the implementation of which the client is offered to present the image of a family chest, assuming that the description will present unconscious family and personal needs, conflicts or affects that form the content of the unconscious. It is indicated that the images are associated with the unconscious, are quite universal and have the status of archetypal images, correlated with existential life situations. Results. It is generalized that in the experimental group, as a result of introducing the technique at the stage of the control diagnostic section, the frequency of expression of the positive modality of all certain empirical indicators is significantly higher than the frequency of expression of it in the control group. It is evidenced that among the representatives of the experimental sample, the number of family members with problem children with the prevailing attitude toward a positive perception and acceptance of a partner or other members of the nuclear family, with a reflexive attitude and readiness to generate a constructive space for marital and family relationships, cultivation of «healthy» family values and attitudes, with the implementation of constructive role-playing patterns of family functioning, turned out to be higher than among representatives of the control sample. It was highlighted that the level of formation of a personal attitude towards a positive perception and acceptance of a partner or other members of the nuclear family, among members of families with problem children, as part of the introduction of psychotherapeutic techniques, is 4,5 times higher. Conclusions. It has been proved that an important component of psychological support for families with problem children is the psychotherapeutic phase using the Family Chest psychotechnique aimed at developing positive changes in relation to family values, family roles, family attitudes, characteristics of spousal and family relationships, adoption of a partner or other members of the nuclear family that have become targets of psychological support. It is noted that promising areas for further research are improving the program of psychological support for families with problem children, drawing up empirical diagnostic programs for the formation of the content of psychological support for families using effective psychotherapeutic techniques.

Key words: family, nuclear family, problem child, psychotherapy, psychotechniques, family attitudes, family roles, psychological support.

Мушкевич Мирослава. Психотерапевтическая техника «Семейный сундук» при психологическом сопровождении семей, что имеют проблем- 
ных детей. Цель. В статье представляются результаты использования в процессе психологического сопровождения психотерапевтической техники «Семейный сундук». Memoды. Описываются основные подходы к применению психотехники, при реализации которой клиенту предлагают представить образ семейного сундука, предполагая, что в описании будут представлены неосознанные семейные и личностные потребности, конфликты или аффекты, образующие содержание бессознательного. Указывается, что образы, связанные с бессознательным, достаточно универсальны и имеют статус архетипических образов, соотносимых с экзистенциальными жизненными ситуациями. Peзультаты. Обобщается, что в экспериментальной группе в результате внедрения техники на этапе контрольного диагностического среза частота выражения положительной модальности всех определенных эмпирических показателей достоверно выше частоты выражения таковой в контрольной группе. Засвидетельствовано, что среди представителей экспериментальной выборки количество членов семей, имеющих проблемных детей, из сложившейся установкой на позитивное восприятие и принятие партнера или других членов ядерной семьи с отрефлексированной позицией и готовностью к генерированию конструктивного пространства супружеских и семейных отношений, культивирование «здоровых» семейных ценностей и установок, реализации конструктивных ролевых паттернов семейного функционирования, оказалась выше, чем среди представителей контрольной выборки. Указывается, что уровень формирования личностной установки на позитивное восприятие и принятие партнера или других членов ядерной семьи у членов семей проблемных детей в рамках внедрения психотерапевтической техники в 4,5 раза выше. Выводы. Доказывается, что важным компонентом психологического сопровождения семей, имеющих проблемных детей, является психотерапевтический этап с использованием психотехники «Семейный сундук», направленной на развитие положительных изменений в отношении семейных ценностей, семейных ролей, семейных установок, особенностей супружеских и семейных отношений, принятие партнера или других членов ядерной семьи, что стали мишенями психологического сопровождения. Отмечается, что перспективными направлениями дальнейших исследований являются совершенствование программы психологического сопровождения семей, имеющих проблемных детей, составление эмпирико-диагностических программ формирования содержания психологического сопровождения семей с использованием эффективных психотерапевтических техник.

Ключевые слова: семья, ядерная семья, проблемный ребенок, психотерапия, психотехника, семейные установки, семейные роли, психологическое сопровождение.

Постановка наукової проблеми та її значення. Психологічний супровід у науковій літературі трактується як комплексний метод, що об’єднує більшість форм, методів і засобів психологічної допомоги, 
спрямованих на особистість та середовище ii життєдіяльності. У нашому випадку таким середовищем є сімейна система, що має проблемну дитину, на рівні функціонування двох підсистем (шлюбної, батьківської), яка стоїть поза межами наукових пошуків, але відіграє важливу роль у становленні позитивної динаміки психологічного функціонування сім’ї. У більшості випадків на сьогодні традиція допомоги сім'ям, що мають проблемних дітей, зосереджена, передусім, на самій дитині, а члени ядерної сім'ї залишаються лише ресурсом, умовою чи ж перепоною. Дослідження обмежуються констатацією необхідності розроблення спеціальних заходів, спрямованих на реабілітацію цієї категорії осіб, а в межах корекції запропоновано консультування батьків спеціалістами різних профілів (психологами, педагогами, лікарями).

У працях науковців найчастіше аналізується аспект участі сім’ї у вихованні та розвитку проблемної дитини. Результати досліджень указують на наявність певних порушень у різних сферах такої сім’і (емоційна сфера, проблеми спілкування із соціумом, соматичні порушення). Увесь цей комплекс порушень автори називають батьківською кризою. Рівень ії важкості залежить від низки обставин: ступеня вираження дефекту поведінки чи прояву дитини; часу, що пройшов із моменту початку деструктивної поведінки; особистісних особливостей батьків і допомоги, наданої фахівцями. Праці стосовно цього питання підтверджують висновки про пряму залежність ставлення батьків до дітей від особливостей особистості самих батьків, їхного стану, життєвого досвіду та меншою мірою - від особливостей дітей. Тобто існує суперечність між соціальною гостротою проблеми, ії психотравмувальною значимістю й відсутністю розроблених технологій психологічної допомоги дорослим членам сімей, котрі мають проблемних дітей.

Аналіз досліджень із цієї проблеми. Психологічний супровід сім’ї - ефективний напрям психологічної допомоги психічно здоровим дорослим членам сім'ї на етапі виникнення труднощів особистісного та міжособистісного функціонування, пов'язаних із проблемною дитиною. Саме визначення поняття «проблемна дитина» включає в себе характеристики психологічно й фізіологічно здорової дитини, але їі поведінкові прояви такі, що дорослі не можуть із нею ефективно взаємодіяти (за умови, що в самих дорослих відсутня проблемна поведінка) (Шарма \& Шарма, 2006). До цієї категорії нале- 
жать агресивні діти, імпульсивні, гіперактивні, невпевнені в собі, депресивні, віктимні, емоційно холодні, байдужі, неконтактні, сором'язливі тощо. У своїх дослідженнях Ж. Глозман до характеристики проблемних дітей уключає непідпорядкованість, що виникає внаслідок індивідуальних особливостей онтогенезу дитини й не пов'язана 3 будь-якою патологією мозку або психіки. За хороших компенсаторних можливостей і сприятливих умов розвитку в сім’ї дитина може досягти середньонормативних показників. В іншому випадку можна очікувати прояви дизонтогенезу та соціальної дезадаптації (Глозман, 2018).

Сутнісною характеристикою психологічного супроводу сім’ї $€$ створення умов для переходу особистості чи сім’ї до самодопомоги. Утрата здатності справлятися з поведінковими проявами дитини, специфіка їі психічного стану по-різному впливають на загальну психологічну й духовну атмосферу сім'ї. Це проявляється в особливостях життєдіяльності сім’ї, стилі життя, стосунках шлюбних партнерів і функціонуванні сім’ї в цілому (Іванова, 2000). Результатом психологічного супроводу є поява нової життєвої якості - адаптивності спроможності самостійно досягати рівноваги із собою й навколишнім світом у різних життєвих ситуаціях. Основа психологічного супроводу - методологічні та теоретичні засади системного підходу, описані в теорії комунікацій Г. Бейтсона (1971), структурній сімейній психотерапії С. Мінухіна (1981), стратегічному підході Дж. Хейлі (1998) і К. Маданес (Маданес, 1999), гуманістичній сімейній психотерапії К. Роджерса (2002), В. Сатір (1999), К. Віттакера (Віттакер \& Бамбері 1997), системному підході до психотерапії М. Боуена (Боуен, 2005). В основі системного підходу - положення про те, що сім'я - єдиний організм, система, що функціонує за своїми законами. Це положення грунтується на холістичному принципі, згідно з яким ціле більше, ніж проста сума частин. Тобто порушення емоційної сфери дитини, поява iii поведінкових симптомів не можуть бути пояснені лише особливостями дитячої психіки. Вони безпосередньо пов'язані з особливостями внутрісімейної взаємодії, які стають контекстом появи цього виду порушень. Тому для зняття симптоматичних проявів і нормалізації емоційного стану дитини, а в нашому дослідженні - дошкільника та молодшого школяра - потрібна робота з усією сім'єю як системою, насамперед із дорослими їі членами на рівні шлюбної та батьківської підсистем. У фокусі роботи - інтрапсихічні проблеми кожного 3 дорослих членів сім’ї й патерни взаємодій і процеси сім’ї загалом. 
Для успішної реалізації психологічного супроводу використовується безліч альтернативних психотерапевтичних прийомів (Шерман $\&$ Фредман, 2001; Фрімен, 2001). Серед них особливе місце займає психотерапевтична техніка, яка являє собою ретельно розроблений план дій, грунтований як на теорії, так і на спостереженнях. Психотехніка має певну мету й застосовується за певних необхідних умов. При цьому кожну конкретну психотехніку можна розглядати одночасно і як психодіагностичний тест, і як психотерапевтичну процедуру. Отже, психотехніка являє собою системну процедуру, за допомогою якої виконується те чи інше комплексне або наукове завдання.

Мета та завдання дослідження передбачають теоретичне й практичне обгрунтування використання психотехніки «Сімейна скриня» в роботі із сім'ями, що мають проблемних дітей, і дослідження іiі психотерапевтичного впливу на сім'ю як систему. Відповідно, критерій оцінки впливу психотехніки на особливості функціонування сімей, котрі мають проблемних дітей, визначається кількома напрямами якісної трансформації процесів особистісно-сімейного функціонування їхніх членів, зокрема розкриттям й активізацією внутрішніх ресурсів, які дають змогу задовольняти потреби ऑї членів, а в подальшому - самостійно розв'язувати проблеми, які виникають, та допомагати в цьому одне одному; психологічною підтримкою функціональних членів сім’і, котрі ініціюватимуть й активно підтримуватимуть процес конструктивної внутрісімейної трансформації; оптимізацією процесів зворотного зв'язку й комунікації між усіма членами

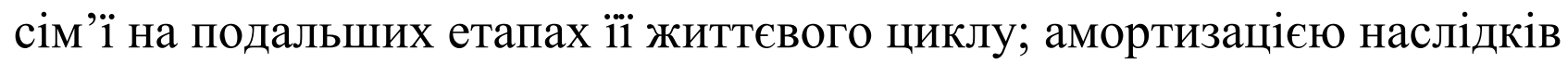
неконструктивного розвитку сімейної системи; активізацією сильних і нівелюванням слабких сторін (аспектів) сімейного функціонування тощо.

Методи та методики. У цій статті розглядаємо психотехніку «Сiмейна скриня», яка задається безпосередньо психотерапевтом. Її тривалість зумовлюється вагою психічних розладів у членів сім'ї, виразністю міжособистісних конфліктів у ній, мотивацією членів сім’і до досягнення терапевтичних змін. Клієнтові пропонують уявити образ сімейної скрині, передбачаючи, що в описі будуть представлені незадоволені сімейні та особистісні потреби, конфлікти або афекти, що утворюють зміст несвідомого. Образи, пов'язані 3 несвідомим, досить універсальні й мають статус архетипових образів, що співвідносяться з екзистенційними життєвими ситуаціями. 
Основу методу становить вільне фантазування у формі образів, «внутрішніх картин» на задану психотерапевтом тему. Психотерапевт при цьому виконує контролюючу, супроводжувальну й спрямувальну функції. Це певною мірою нагадує психотерапію за методом символдрами, яку можна представити як певну тривимірну систему координат, де одна вісь являє собою роботу з конфліктами (перша складова), інша - роботу, спрямовану на задоволення архаїчних потреб (другий компонент) і третя - робота, націлена на розвиток креативності клієнта (третій складник). При цьому клієнт описує свої актуальні переживання, символічно представляючи несвідомі чи передсвідомі переживання (Барке, 2008; Кісарчук, 2007; Кісарчук, Гребінь, Омельченко, Біла \& Лазос, 2016; Кісарчук \& Гребінь, 2017; Кісарчук, Лазос \& Омельченко, 2014; Льойнер, 2010; Печій, 2012).

Усе, про що розповідає клієнт, описуючи задані образи психотерапевтичної техніки - реальне, лишень не в соціальному, матеріальному світі, а у світі психічного. Героями стають думки, почуття, нереалізовані прагнення, враження від сімейної взаємодії й сімейного функціонування загалом. Розвиток сюжету, його перипетії символічно передають динаміку переживань. У фіналі проведення психотехніки відбувається розв'язання проблеми, набуття відповідей на непрості запитання про себе та сімейне життя. Багатство уяви клієнта дає психотерапевтові плідні можливості для психодіагностичної й психотерапевтичної роботи, оскільки образ сімейної скрині не лише відображає минулий досвід сімейного та особистісного функціонування, але й формує та будує майбутнє бачення позитивних змін. Психотехніка «Сімейна скриня», в основу якої покладено образи, фантазію й метафори, тісно пов'язана 3 проективно-експресивною стороною людської поведінки. Створюється ситуація, яка для клієнта $\epsilon$ проективною. Це дає можливість отримати більш адекватну картину сімейної системи. Окрім того, психотерапевт може використовувати образи, щоб спонукати клієнта застосовувати нові можливості в конкретній життєвій ситуації, роблячи бажані зміни реальними.

Тобто психотехніка «Сімейна скриня» - ще одна ефективна техніка в психотерапії сімейної системи. Звичайно ж, «скриня» - це метафора, а ії вміст - аж ніяк не ювелірні вироби, векселі та цінні папери, а життєвий досвід, перейнятий і засвоєний протягом усього життя. Це - розуміння «хорошого» й «поганого», «правильного» та «неправильного», сімейні цінності, установки, традиції й готові 
«ідеальні» образи, переконання тощо. У сімейній скрині зберігається безліч таємниць, загадок, сімейних міфів, переказів, прихованих приписів, заборон, потужних послань нащадкам. Усі ці «коштовності» впливають на становлення особистості.

У скрині зберігається багата спадщина, із якої кожен бере для себе щось, але найчастіше не усвідомлює це (окрім сімейних традицій, цінностей, переконань, установок, у ній зберігаються, наприклад, страхи бути успішними, або не проявляти ініціативу, не бути близькими $з$ іншими людьми, тримати образи в собі та ін.). Усе це передається із покоління в покоління, саме те, що було актуальним для прабатьків. Багаж сімейної скрині складається 3 низки важливих чинників, як-от: стиль спілкування, прийнятий у сім’ї; сімейні ролі та їх бачення; ставлення до розширеної сімейної системи; стратегії вираження почуттів, прийняті в сім'ї; сімейні традиції. Основними емпіричними показниками сімейної скрині є сімейні цінності; сімейні ролі; сімейні установки; особливості шлюбних і сімейних взаємин та ставлення; прийняття партнера чи інших членів ядерної сім’ї.

Виклад основного матеріалу й обгрунтування отриманих результатів дослідження. Операціоналізацію емпіричних показників здійснено за допомогою аналізу прийняття та ставлення до кожного члена сім'ї й сімейної ситуації в цілому. Для проведення дослідження використано квазіекспериментальний міжсуб'єктний план з експериментальною та контрольною групами, учасники яких характеризувались однаковими соціально-демографічними, економічними й професійними характеристиками. Цього досягнуто за допомогою процедури блокової рандомізації, що дало змогу отримати дві репрезентативні, еквівалентні в змістовно-структурному й кількісному плані, вибірки досліджуваних - експериментальну (48 осіб) і контрольну (48 осіб).

Щодо оцінки впливу психотехніки «Сімейна скриня» на членів сімей, що мають проблемних дітей, за критеріями «рівень розвитку показників особистісного функціонування» й «рівень розвитку показників сімейного функціонування» в межах кожної дослідницької групи (експериментальної та контрольної) виокремлено по чотири кластери досліджуваних із різним психотипічним профілем. Операціоналізація показників психотипічних властивостей досліджуваних і визначення релевантних їм емпіричних корелятів дає змогу на конкретно-емпіричному рівні вивчати динаміку змін змістовноструктурних елементів особистості кожного типу досліджуваних у межах реалізації психотехніки. 
Виокремлено досліджуваних із низьким рівнем інтровертованопедантичної особистісної диспозиції (12 осіб); із високим рівнем психостенічної особистісної диспозиції (12 осіб), із високим рівнем потуральної виховної диспозиції (12 осіб), із високим рівнем домінантно-агресивної особистісної диспозиції (12 осіб). Потреба в цьому визначалася, передусім, тим, що зміст, форма й характер формувальних заходів у межах реалізації психотехніки щодо кожного типу членів сімей, що мають проблемних дітей (психотипічного профілю), мають різну якісну специфіку й модальність, що забезпечує ширші можливості та умови для диференційованої й повної, тому й ефективної реалізації психотехніки. Якщо конкретизувати неконструктивні психотипічні профілі (типи) членів сімей, що мають проблемних дітей, які беруть участь в апробації психотехніки, то для типу досліджуваних із низьким рівнем інтровертовано-педантичної особистісної диспозиції важливим буде розвиток здорового консервативного педантизму на основі особистісної інтровертованої орієнтації; для типу досліджуваних із високим рівнем домінантно-агресивної особистісної диспозиції визначальним стане нівелювання поведінкових атрибутів маскулінного патерну, трансформація в соціально прийнятні форми особистісних проявів реактивної та спонтанної агресивності; для типу досліджуваних із високим рівнем психостенічної особистісної диспозиції важливим буде нівелювання тривожних тенденцій із проявами постійної невпевненості в собі, нерішучості, боязливості й уразливості; для типу досліджуваних із високим рівнем потуральної виховної диспозиції потрібна конструктивна трансформація стратегії потуральної протекції у сфері виховання дитини, ефективна зміна їх неконструктивної особистісної позиції, пов'язаної 3 вихованням у дитини некритичної вседозволеності та доступності об'єкта бажань і потреб.

Незалежна змінна експерименту - психотерапія членів сімей, що мають проблемних дітей, засобом психотехніки «Сімейна скриня». Залежна змінна експерименту - результативність подолання неконструктивних особистісних настанов членів сімей, що мають проблемних дітей, ступінь конструктивного розвитку властивостей їхньої особистісної структури, а також формування якісної структури їх особистісно-сімейного функціонування.

В експериментальній групі всі завдання реалізації техніки мали чітко структурований та організований характер і були побудовані на 
психологічних принципах. Формувальні заходи щодо досліджуваних, які ввійшли до контрольної групи, відбувалися на основі стандартного підходу, типового технологічного сценарію психологічної допомоги без використання психотехніки «Сімейна скриня».

У межах верифікації першого критерію оцінки ефективності психотехніки застосовано непараметричний статистичний критерій відмінностей Вілкоксона (Wilcoxon Signed Ranks Test) (Наслєдов, 2005). Із його допомогою визначено статистично достовірні відмінності в рівні вираження емпіричних показників у досліджуваних із різним психотипічним профілем (типом) до й після реалізації типового технологічного сценарію психологічної допомоги, а також в умовах упровадження спеціальної психотехніки «Сімейна скриня».

Верифікацію за другим критерієм оцінки ефективності психотехніки здійснено за допомогою непараметричного статистичного критерію Хi-квадрат Пірсона (Chi-Square Test), а також обчислення показника відношення шансів (Odds Ratio - OR) (Наслєдов, 2004). Перший критерій використовували для порівняння двох емпіричних розподілів якісних ознак, отриманих на двох незалежних вибірках - експериментальній і контрольній. Другий статистичний показник забезпечив визначення пропорції частотного відношення якісної ознаки в експериментальній і контрольній вибірках.

Під час аналізу змін у рівні вираження емпіричних показників досліджуваних різного психотипічного профілю виявлено відмінності за результатами двох діагностичних зрізів в експериментальній i контрольній вибірках. Проаналізуємо послідовно результати порівняння вираження емпіричних показників у досліджуваних обох груп до й після застосування традиційної програми психологічної допомоги, а також в умовах упровадження спеціальної психотехніки «Сімейна скриня».

Порівняння частоти вираження позитивної та негативної модальності визначених емпіричних показників у досліджуваних експериментальної та контрольної вибірок підтверджує статистично значущий характер їхніх відмінностей за всіма шкалами психотерапевтичної техніки «Сімейна скриня»: «прийняття партнера або інших членів ядерної сім'ї» $(\mathrm{p}<0,001)$, «подружні та сімейні взаємини й ставлення» $(\mathrm{p}<0,001)$, «сімейні цінності» $(\mathrm{p}<0,01)$, «сімейні установки» $(\mathrm{p}<0,01)$, «сімейні ролі» $(\mathrm{p}<0,01)$ (див. табл. 1$)$. 
Таблиия 1
Розподіл частоти модальностей емпіричних показників
в експериментальній і контрольній вибірках за шкалами психотехніки «Сімейна скриня»

\begin{tabular}{|c|c|c|c|c|}
\hline \multicolumn{2}{|c|}{ Емпіричний показник } & $\begin{array}{c}\text { Експери- } \\
\text { ментальна }\end{array}$ & $\begin{array}{c}\text { Контрольна } \\
\text { група }\end{array}$ & $\mathbf{P}$ \\
\hline \multirow{2}{*}{$\begin{array}{l}\text { Сімейні } \\
\text { цінності }\end{array}$} & $\begin{array}{l}\text { частота позитивної } \\
\text { модальності }\end{array}$ & 34 & 21 & \multirow{2}{*}{0,007} \\
\hline & $\begin{array}{l}\text { частота негативної } \\
\text { модальності }\end{array}$ & 14 & 27 & \\
\hline \multirow{2}{*}{ Сімейні ролі } & $\begin{array}{l}\text { частота позитивної } \\
\text { модальності }\end{array}$ & 38 & 26 & \multirow{2}{*}{0,009} \\
\hline & $\begin{array}{l}\text { частота негативної } \\
\text { модальності }\end{array}$ & 10 & 22 & \\
\hline \multirow{2}{*}{$\begin{array}{l}\text { Сімейні } \\
\text { установки }\end{array}$} & $\begin{array}{l}\text { частота позитивної } \\
\text { модальності }\end{array}$ & 39 & 27 & \multirow{2}{*}{0,008} \\
\hline & $\begin{array}{l}\text { частота негативної } \\
\text { модальності }\end{array}$ & 9 & 21 & \\
\hline \multirow{2}{*}{$\begin{array}{l}\text { Подружні } \\
\text { та сімейні } \\
\text { взасмини } \\
\text { й ставлення }\end{array}$} & $\begin{array}{l}\text { частота позитивної } \\
\text { модальності }\end{array}$ & 34 & 18 & \multirow{2}{*}{0,001} \\
\hline & $\begin{array}{l}\text { частота негативної } \\
\text { модальності }\end{array}$ & 14 & 30 & \\
\hline \multirow{2}{*}{$\begin{array}{l}\text { Прийняття } \\
\text { партнера } \\
\text { або інших } \\
\text { членів } \\
\text { ядерної сім'ї }\end{array}$} & $\begin{array}{l}\text { частота позитивної } \\
\text { модальності }\end{array}$ & 36 & 19 & \multirow[b]{2}{*}{0,000} \\
\hline & $\begin{array}{l}\text { частота негативної } \\
\text { модальності }\end{array}$ & 12 & 29 & \\
\hline
\end{tabular}

Дані таблиці дають підставу констатувати, що в експериментальній групі внаслідок упровадження спеціальної психотехніки на етапі контрольного діагностичного зрізу частота вираження позитивної модальності всіх визначених емпіричних показників достовірно вища за частоту вираження такої в контрольній групі. Це засвідчує, що серед представників експериментальної вибірки кількість членів сімей проблемних дітей зі сформованою настановою на позитивне сприйняття й прийняття партнера або інших членів ядерної сім'ї 3 відрефлексованою позицією та готовністю до генерування конструктивного простору подружніх і сімейних взаємин, культивування «здорових» сімейних цінностей та настанов, реалізації конструктивних 
рольових патернів сімейного функціонування, виявилася більшою, ніж серед представників контрольної вибірки.

Проаналізуємо пропорції частотного відношення якісної ознаки (iіi позитивної модальності до негативної модальності) в експериментальній і контрольній вибірках для всіх шкал психотерапевтичної техніки «Сімейна скриня».

Для шкали «Прийняття партнера або інших членів ядерної сім’ї» пропорція частотного відношення якісної ознаки (iі позитивної модальності до негативної) в експериментальній і контрольній вибірках становить 4,579/1. Тобто шанс формування особистісної настанови на позитивне сприйняття й прийняття партнера або інших членів ядерної сім'ї в членів сімей проблемних дітей у межах упровадження спеціальної психотехніки в 4,5 раза вищий, ніж після застосування традиційної програми психологічної допомоги.

Щодо шкали «Подружні та сімейні взаємини i ставлення» пропорція частотного відношення якісної ознаки (iї позитивної модальності до негативної) в експериментальній і контрольній вибірках становить 4,048/1. Тобто шанс формування відрефлексованої позиції та готовності до генерування конструктивного простору подружніх і сімейних взаємин у членів сімей, що мають проблемних дітей, у межах спеціальної психотехніки в чотири рази вищий, ніж після традиційної програми психологічної допомоги.

Якщо проаналізувати показник відношення шансів для шкали «Сімейні цінності», то для неї пропорція частотного відношення якісної ознаки (iї позитивної модальності до негативної) в експериментальній і контрольній вибірках становить 3,122/1. Це свідчить, що шанс сформувати «здорові» сімейні цінності в членів сімей, що мають проблемних дітей у межах упровадження спеціальної психотехніки більш ніж утричі вищий, ніж після застосування традиційної технології психологічної допомоги.

Для шкали «Сімейні установки» пропорція частотного відношення якісної ознаки (iї позитивної модальності до негативної) в експериментальній і контрольній вибірках становить 3,370/1. Тобто шанс розвитку конструктивних сімейних настанов у членів сімей, що мають проблемних дітей у межах упровадження спеціальної психотехніки утричі вищий, ніж після застосування традиційної технології психологічної допомоги. 
Щодо шкали «Сімейні ролі» пропорція частотного відношення якісної ознаки (iї позитивної модальності до негативної) в експериментальній і контрольній вибірках становить 3,215/1. Тому шанс розвитку та реалізації конструктивних рольових патернів сімейного функціонування в членів сімей, що мають проблемних дітей у межах спеціальної психотехніки більш ніж утричі вищий, ніж після традиційної технології психологічної допомоги.

Висновки й перспективи подальших досліджень. Отже, порівняння частоти вираженості позитивної та негативної модальності визначених емпіричних показників у досліджуваних експериментальної й контрольної вибірок дає підставу підтвердити статистично значущий характер їхніх відмінностей за всіма шкалами психотерапевтичної техніки «Сімейна скриня»: «прийняття партнера або інших членів ядерної сім’ї» $(\mathrm{p}<0,001)$, «подружні й сімейні взаємини та ставлення» $(p<0,001)$, «сімейні цінності» $(p<0,01)$, «сімейні установки» $(p<0,01)$, «сімейні ролі» $(\mathrm{p}<0,01)$. Це свідчить про те, що серед представників експериментальної вибірки кількість членів сімей, що мають проблемних дітей, зі сформованою настановою на позитивне сприйняття й прийняття партнера або інших членів ядерної сім’ї із відрефлексованою позицією й готовністю до генерування конструктивного простору подружніх і сімейних взаємин, до культивування «здорових» сімейних цінностей та настанов, до реалізації конструктивних рольових патернів сімейного функціонування виявилася суттєво більшою, ніж серед представників контрольної вибірки.

Отже, доведено, що важливим компонентом психологічного супроводу сімей, котрі мають проблемних дітей, є психотерапевтичний етап із використанням психотехніки «Сімейна скриня», спрямованої на розвиток позитивних змін щодо сімейних цінностей, сімейних ролей, сімейних установок, особливостей подружніх і сімейних взаємин і ставлення, прийняття партнера чи інших членів ядерної сім'ї, що стали мішенями психологічного супроводу. Виявлено, що позитивне сприйняття та прийняття партнера або інших членів ядерної сім'ї із відрефлексованою позицією й готовністю до генерування конструктивного простору подружніх і сімейних взаємин, культивування «здорових» сімейних цінностей та настанов, реалізації конструктивних рольових патернів сімейного функціонування $є$ вищим у представників експериментальної групи, ніж серед представників контрольної вибірки. 
Перспективними напрямами наукової роботи $\epsilon$ вдосконалення програми психологічного супроводу сімей, що мають проблемних дітей; поглиблення знань про структурно-функціональні особливості iii складових частин; детальне розкриття «особистісного й сімейного виміру» особистості відповідно до структурних компонентів, таких як вік, гендерна диференціація тип сім’ї, склад сім’і; складання емпірико-діагностичних програм формування змісту психологічного супроводу сімей із використанням ефективних психотерапевтичних технік.

\section{Література}

1. Барке, У. (2008). Психотерапия действует - посредством чего помагает кататимно-имагинативная психотерапия? Размышления о действующих факторах психотерапию. Кататимно-имагинативная психотерапия как психодинамическая образная психотерапия. Москва: Атмосфера, 61-79.

2. Боуэн, М. (2005). Теория семейных систем Мюррея Боуэна: основные понятия, методы и клиническая практика. Москва: Когито-центр, 342 с.

3. Витакер, К., Бамбери, В. (1997). Таниы с семьёй. Москва: Класс, 142 с.

4. Глозман, Ж. М. (2018). Нейропсихология детского возраста. Москва: Изд-во «Юрайт», 249 с.

5. Іванова, І. Б. (2000). Соціальні проблеми дітей і батьків у контексті їхнього ставлення до ситуації. Соціально-психологічні проблеми дітей-інвалідів. Київ: Логос, 58-74.

6. Кисарчук, 3. Г. (2007). Теоретико-методологические предпосылки выделения трех ступеней в символдраме. Актуальні проблеми психологіï, 3, 147-157.

7. Кісарчук, 3. Г., Гребінь, Л. О. (2017). Метод кататимно-імагінативної психотерапії в контексті особливостей його викладання. Актуальні проблеми психологї, 3, 13, 203-255.

8. Кісарчук, 3. Г., Гребінь, Л. О., Омельченко, Я. М. (2016). Кататимноімагінативна психотерапія як метод допомоги постраждалим дітям. Психологічна допомога дітям у кризових ситуачіях: методи і техніки: метод. посіб. Київ: Логос, 232 c.

9. Кісарчук, 3. Г., Омельченко, Я. М., Лазос, Г. П. (2014). Кататимно-імагінативна психотерапія: теоретичні та технологічні аспекти застосування у вітчизняному психотерапевтичному просторі. Теорії і технології застосування сучасних підходів до психотерапії у вітчизняних соціокультурних умовах: монографія. Київ; Кіровоград: Імекс-ЛТД, 8-37.

10. Лёйнер, Х. (2010). Средняя ступень символдрамы. Введение: оиенка значения средней ступени. Символдрама. Запорожье: Креамист, 4-8.

11. Маданес, К. (1999). Стратегическая семейная терапия. Москва: Класс, $272 \mathrm{c}$.

12. Наследов, А. Д. (2005). SPSS: компьютерный анализ данных в психологии и социальных науках. Санкт-Петербург: Питер, 416 с. 
13. Печій, П. (2012). Символдрама в кризовій інтервенції. Форум психіampiï ma nсихотерапіï, 7, 84-89.

14. Фримен, Д. (2001). Техники семейной психотерапии. Санкт-Петербург: Питер, 384 с.

15. Шерман, Р., Фредман, Н. (2001). Структурированные техники семейной терапии: руководство. Москва, 336 с.

16. Bateson, G. (1971). A systems approach. Intenational Journal of Psychiatry, 9, 242-244.

17. Sharma, R. N., Sharma, R. (2006). Childm Psychology. Atlantic Publishers and Distributors, $327 \mathrm{p}$.

\section{References}

1. Barke, U. (2008). Psihoterapija dejstvuet - posredstvom chego pomagaet katatimno-imaginativnaja psihoterapija? Razmyshlenija o dejstvujushhih faktorah psihoterapiju [Does psychotherapy work - where does catatymo-imaginative psychotherapy help? Reflections on the Acting Factors of Psychotherapy]. Katatimno-imaginativnaja psihoterapija kak psihodinamicheskaja obraznaja psihoterapija. Moskva: «Atmosfera», 61-79 (in Russian).

2. Boujen, M. (2005). Teorija semejnyh sistem Mjurreja Boujena: osnovnye ponjatija, metody $i$ klinicheskaja praktika [Murray Bowen's Theory of Family Systems: Basic Concepts, Methods, and Clinical Practice]. Moskva: Kogito-centr, 342 p. (in Russian).

3. Vitaker, K., Bamberi, V. (1997). Tancy s sem'joj [Dancing with family]. Moskva: Klass, 142 p. (in Russian).

4. Glozman, Zh. M. (2018). Nejropsihologija detskogo vozrasta [Pediatric Neuropsychology]. Moskva: Izd-vo «Jurajt», 249 p. (in Russian).

5. Ivanova, I. B. (2000). Sotsialni problemy ditei i batkiv u konteksti yikhnoho stavlennia do sytuatsii [Social problems of children and parents in the context of their attitude to the situation]. Sotsialno-psykholohichni problemy ditei-invalidiv. Kyiv: Lohos, 58-74 (in Ukrainian).

6. Kisarchuk, Z. G. (2007). Teoretiko-metodologicheskie predposylki vydelenija treh stupenej v simvoldrame [Theoretical and methodological prerequisites for the allocation of three steps in the symboldrama]. Aktual'ni problemi psihologiï, 3, 147157 (in Russian).

7. Kisarchuk, Z. H., Hrebin, L. O. (2017). Metod katatymno-imahinatyvnoi psykhoterapii v konteksti osoblyvostei yoho vykladannia [The method of catatimnoimaginative psychotherapy in the context of the peculiarities of its teaching]. Aktualni problemy psykholohii, 3, 13, 203-255 (in Ukrainian).

8. Kisarchuk, Z. H., Hrebin, L. O., Omelchenko, Ya. M. (2016). Katatymnoimahinatyvna psykhoterapiia yak metod dopomohy postrazhdalym ditiam [Catatimno-imaginative psychotherapy as a method of helping affected children]. Psykholohichna dopomoha ditiam u kryzovykh sytuatsiiakh: metody $i$ tekhniky: metod. posib. Kyiv: Lohos, 232 p. (in Ukrainian). 
9. Kisarchuk, Z. H., Omelchenko, Ya. M., Lazos, H. P. (2014). Katatymnoimahinatyvna psykhoterapiia: teoretychni ta tekhnolohichni aspekty zastosuvannia $\mathrm{u}$ vitchyznianomu psykhoterapevtychnomu prostori [Catatimno-imaginative psychotherapy: theoretical and technological aspects of application in the domestic psychotherapeutic space]. Teorii i tekhnolohii zastosuvannia suchasnykh pidkhodiv do psykhoterapii u vitchyznianykh sotsiokulturnykh umovakh: monohrafiia. Kyiv; Kirovohrad: Imeks-LTD, 8-37 (in Ukrainian).

10. Ljojner, H. (2010). Srednjaja stupen' simvoldramy. Vvedenie: ocenka znachenija srednej stupeni [The middle stage of the symbolic drama. Introduction: assessment of the value of the middle stage. Symboldrama]. Simvoldrama. Zaporozh'e: «Kreamist», 4-8 (in Russian).

11. Madanes, K. (1999). Strategicheskaja semejnaja terapija [Strategic Family Therapy]. Moskva: Klass, 272 p. (in Russian).

12. Nasledov, A. D. (2005). SPSS: komp'juternyj analiz dannyh v psihologii $i$ social'nyh naukah [SPSS: computer data analysis in psychology and social sciences]. Sankt-Peterburg: Piter, 416 p. (in Russian).

13. Pechii, P. (2012). Symvoldrama v kryzovii interventsii [Symboldrama in crisis intervention]. Forum psykhiatrii ta psykhoterapii, 7, 84-89 (in Ukrainian).

14. Frimen, D. (2001). Tehniki semejnoj psihoterapii [Family Psychotherapy Techniques]. Sankt-Peterburg: Piter, 384 p. (in Russian).

15. Sherman, R., Fredman, N. (2001). Strukturirovannye tehniki semejnoj terapii: rukovodstvo [Structured Family Therapy Techniques: Guides]. Moskva, 336 p. (in Russian).

16. Bateson, G. (1971). A systems approach. Intenational Journal of Psychiatry, 9, 242-244 (in English).

17. Sharma, R. N., Sharma, R. (2006). Childm Psychology. Atlantic Publishers and Distributors, 327 p. (in English).

Received: 09.01.2020

Accepted: 05.02.2020 